American Journal of Applied Sciences 6 (3): 393-395, 2009

ISSN 1546-9239

(C) 2009 Science Publications

\title{
Charcoal-Oil Mixture as an Alternative Fuel: A Preliminary Study
}

\author{
Roila Awang and Choo Yuen May \\ Engineering and Processing Division, Malaysian Palm Oil Board \\ No.6, Persiaran Institusi, Bandar Baru Bangi, 43000 Kajang, Selangor, Malaysia
}

\begin{abstract}
The fast depletion of fuel oil and continuous increase in the demand for power is a global issue. The world energy consumption is projected to grow at an average of 2.7-3.7\% from 1996 to 2010. Therefore search for alternative fuel is highly prioritized. Thus this study presents the results on the characteristic of charcoal-oil mixture as an alternative fuel. The calorific value, ash content and stability of the mixture are determined.
\end{abstract}

Key words: Charcoal, fuel, palm oil, mixture

\section{INTRODUCTION}

Energy is one of the key factors in the development of a country. Over the years, the demand for energy will increase from industrialization, more transport required and also from growing population. To minimize problems on power shortages in the future. One of the option is to develop a non-conventional form of fuel that can be obtained through biomass and wood gasification, emulsification of liquid fuel, briquetting of solid waste and liquefaction or slurring of $\mathrm{coal}^{[1,2]}$. US patent 4201552 claimed that a coal-oil mixture was cheaper than oil, easier to handle, more combustible than coal and economical to store. However it was not cheaper than coal ${ }^{[3]}$. Presently, industrial power plants utilize liquid hydrocarbons as fuel because of their energy content and availability. On the other hand, many power plants utilized solid fuel such as coal since it is much less expensive than liquid fuel ${ }^{[3]}$. Attempts to utilize both types of fuel in admixture have not been successful because the dispersions obtained have not been sufficiently stable. Therefore, it would be highly desirable to provide coal-oil fuel slurries, which are stable in that the coal remains dispersed in the oil. The objective of this work is to produce charcoal-oil mixture from palm-based materials as an alternative fuel.

\section{MATERIALS AND METHODS}

Preparation of Charcoal-Oil Mixture (COM): The charcoal-oil slurry or dispersion was prepared by heating the oil to a temperature of $50^{\circ} \mathrm{C}$ and adding to stabilizer to the oil in the desired quantity based on weight. The charcoal was then added to the oilstabilizer composition and the resultant composition was stirred vigorously, usually within $30 \mathrm{~min}$, to ensure uniform mixing.

Physical and chemical properties determination: Viscosities of all fuels were determined at room temperature. A Brookfield viscometer (Brookfield Engineering Laboratories, Inc., Stougton, MA) with adapter was used. Gross energy content or heat of combustion of all fuel was determined according to ASTM method D240-92 ${ }^{[5]}$. A LECO AC 350 automatic oxygen bom calorimeter (LECO Corporation, Michigan, USA) was used.

The density of the fuel was determined using Metler Toledo Densitometer. The ash content was determined according to ASTM D482-46 ${ }^{[4]}$. The shelf life and stability of the COM fuel were also considered. This was done by storing the fuel in a graduated cylinder and was closely monitored in a timely sequence.

\section{RESULTS AND DISCUSSION}

The results have shown that as the charcoal content increases, most of the COM fuel properties also increase (Table 1), but it was observed the calorific value decreases. The increasing COM fuel properties include ash content, density, viscosity, \% sediment, shelf life and stability. The decrease in calorific value is due to the presence of excessive ash content and \% sediment caused by the increase of charcoal

Corresponding Author: Dr. Roila Awang, Engineering and Processing Division, Malaysian Palm Oil Board No. 6, Persiaran Institusi, Bandar Baru Bangi, 43000 Kajang, Selangor, Malaysia Tel: 60387694558 Fax: 603-89266197 
Am. J. Applied Sci., 6 (3): 393-395, 2009

Table 1: Summary of fuel samples properties

\begin{tabular}{llllll}
\hline $\begin{array}{l}\text { Fuel } \\
\text { sample }\end{array}$ & $\begin{array}{l}(\%) \\
\text { Ash }\end{array}$ & Density & $\begin{array}{l}\text { Calorific } \\
\text { value, } \mathrm{J} \mathrm{g}^{-1}\end{array}$ & $\begin{array}{l}\text { Viscosity, } \\
\mathrm{cP}\end{array}$ & $\begin{array}{l}(\%) \\
\text { Sed }\end{array}$ \\
\hline $\begin{array}{l}\text { Oil } \\
\text { Charcoal }\end{array}$ & 0.02 & 0.8722 & 39787 & 5.5 & - \\
COM fuel & & ND & 29209 & $\mathrm{ND}$ & - \\
5 C & 0.32 & 0.9076 & 39258 & 6.9 & 22.92 \\
10 C & 0.46 & 0.9317 & 38966 & 10.5 & 39.58 \\
15 C & 0.66 & 0.9479 & 38357 & 14.5 & 58.70 \\
20 C & 0.87 & 0.9887 & 37889 & $\mathrm{ND}$ & 71.71 \\
\hline
\end{tabular}

ND = Not determined; $5 \mathrm{C}=5 \%$ Charcoal; $10 \mathrm{C}=10 \%$ Charcoal; $15 \mathrm{C}=15 \%$ Charcoal; $20 \mathrm{C}=20 \%$ Charcoal

Table 2: Stability and flow properties of tested COM fuel

\begin{tabular}{lllll}
\hline & & & \multicolumn{2}{l}{$\begin{array}{l}\text { Time taken to drain } \\
\text { column, min }\end{array}$} \\
Fuel & Oil layer (\%) & & $-1-$ & ----- \\
sample & w/o & With & w/o & With \\
& Stabilizer & stabilizer & Stabilizer & stabilizer \\
\hline 5C & 77.08 & 51.02 & 6.9 & 5.7 \\
$10 \mathrm{C}$ & 60.42 & 22.45 & 10.5 & 9.3 \\
15C & 41.32 & 4.35 & 14.9 & 12.8 \\
20C & 28.26 & 4.00 & - & 37.9 \\
\hline
\end{tabular}

concentration. A COM fuel with a low heating value has a prolonged ignition time resulting to higher flash point. Another significant observation shows that the shelf life and stability has improved with an increase of charcoal concentration. Visual observation showed that some difficulties were encountered in maintaining the charcoal in suspension due to rapid settling of relatively course particles. Better stability could be obtained by adding stabilizer to the COM (Table 2). Moreover, the stabilized COM has improved rheological or flow properties over the corresponding unstabilized COM as measured by the time required for the COM to flow through a small orifice.

As pointed out by Manning and Taylor ${ }^{[5]}$, a suspension of powdered coal in oil usually will be unstable with progressive deposition of coal particles at rates dependent on (i) size of coal particles, (ii) viscosity of the oil, (ii) concentration of the suspension and (iv) specific gravities of the component. The stability of the colloid can be promoted by the following techniques:

- Finer grinding

- Establishing a gel structure in the oil with a chemical additive or stabilizer

- Using a peptizing agent

- Selecting oil that gives a stable suspension without adding a stabilizer

It was also reported that to obtain systems with sedimentation and aggregate stability and a low viscosity levels, they must have pronounced

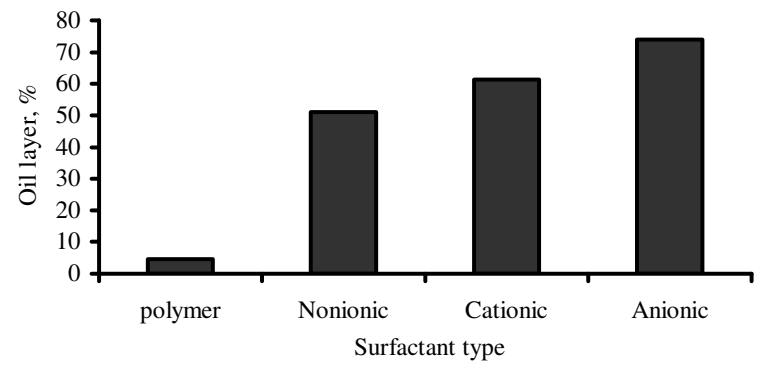

Fig. 1: Effect of various type of surfactant on the stability of COM fuel

Table 3: Effect of surfactant concentration on the stability and heating value of COM fuel containing $5 \%$ charcoal

\begin{tabular}{lll}
\hline Surfactant conc., \% & Stability & Calorific value, $\mathrm{J} \mathrm{g}^{-1}$ \\
\hline 0.0 & 0.96 & 39365 \\
0.5 & 0.36 & 39248 \\
1.0 & 0.32 & 39199 \\
2.0 & 0.20 & 38990 \\
3.0 & 0.20 & 38963 \\
\hline Stability = (Separated oil layer/total volume)
\end{tabular}

$\underline{\text { Table 4: Energy content of COM using various types of palm biomass }}$ Energy content, $\mathrm{J} \mathrm{g}^{-1}$

\begin{tabular}{llll} 
Oil & EFB & Shell & Mesocarp \\
\hline PD & 41110 & 41050 & 40296 \\
CPO & 39718 & 39123 & 38983 \\
RBDPO & 39585 & 38975 & 39278 \\
PB & 39788 & 39657 & 39512 \\
\hline
\end{tabular}

PD = Petroleum diesel $;$ CPO = Crude palm oil; RBDPO = Refined, bleached and deodorized palm oil; $\mathrm{PB}=$ Palm biodiesel; $\mathrm{EFB}=$ Empty fruit bunch

plasticizing, stabilizing and emulsifying properties. Surfactants of different types such as anionic, nonionic and polymeric can be used to stabilize coal-oil mixture system $^{[6]}$.

The stability of COM fuel using various types of surfactant/stabilizer is shown in Fig. 1. The general pattern of the results showed that the stability decreases in the following order: polymeric $>$ nonionic $>$ cationic $>$ anionic. Due to the availability of material, nonionic surfactant was chosen for further evaluation. The influence of the surfactant concentration on the stability, calorific value and pour point was also studied (Table 3). Adding surfactant up to 3\% increased the stability of the system but did not show any difference in pour point of the fuel. Slightly decreased in calorific value was also observed with increasing of surfactant concentration.

In the second group of experiment, the energy content COM using various types of palm biomass was evaluated (Table 4). The gross energy content for COM containing palm oil and palm biodiesel as a liquid part 
is lower than that of containing petroleum diesel. Georing et $a l^{[7]}$ reported that gross heat content of differently processed vegetable oils was less than that of petroleum diesel. COM fuel using empty fruit bunch as a solid part gave higher energy content than shell and mesocarp.

\section{CONCLUSION}

Charcoal-oil mixture can be produced from palmbased material. Adding stabilizer or using smaller particle size of charcoal can increase the stability of the slurry. The stability tends to increase with charcoal concentration.

\section{ACKNOWLEDGEMENT}

The authors would like to thank Director General of MPOB for his permission to publish this study

\section{REFERENCES}

1. Menegdeg, F.G., 1998. Boiler performance of emulsified fuel. Philippine Eng. J., 19: 67-68.
2. Maglaya, A.B., 2005. Utilizing philippine calatrava Coal-Diesel Oil Mixture (CDOM) as alternative fuel for industrial steam generator. Fuel, 84: 29-35.

3. Rowell, R.L. and S.R. Vasconcellos, 1980. Coal-oil slurry compositions. US patent 4201552.

4. Annual Book of ASTM Standards, 1994. American Society for Testing and Materials, Philadelphia.

5. Fawzi, A.A., M.S. Ahmad and M.M. Osman, 1996. Physicochemical characterization of emulsion fuel from fuel oil-water-charcoal and surfactants. Fuel, 75: 1193-1195.

6. Khil'ko, S.L. and E.V. Titov, 2007. Physicochemical aspect of manufacture of threephase colloidal fuels. Chem. Tech. Fuels Oils, 43: 75-82.

7. Georing, C.E., A.W. Schwab, M.J. Daugherty, E.H. Pryde and A.J. Hoakin, 1982. Fuel properties of eleven vegetables oils. Trans. ASAE, 25: 1472. 